\title{
New Staphylinidae (Coleoptera) records with new collection data from New Brunswick and eastern Canada:Tachyporinae
}

\author{
Reginald P. Webster', Jon D. Sweeney', Ian DeMerchant' \\ I Natural Resources Canada, Canadian Forest Service - Atlantic Forestry Centre, 1350 Regent St., P.O. Box \\ 4000, Fredericton, NB, Canada E3B 5P7 \\ Corresponding author: Reginald P. Webster (reginaldwebster@rogers.com) \\ Academic editor:J. Klimaszewski | Received 5 December 2011 | Accepted 20 January 2012 | Published 26 April 2012 \\ Citation: Webster RP, Sweeney JD, DeMerchant I (2012) New Staphylinidae (Coleoptera) records with new collection \\ data from New Brunswick and eastern Canada: Tachyporinae. In: Klimaszewski J, Anderson R (Eds) Biosystematics and \\ Ecology of Canadian Staphylinidae (Coleoptera) II. ZooKeys 186: 55-82. doi: 10.3897/zookeys.186.2491
}

\begin{abstract}
Twenty-three species of Tachyporinae are newly recorded from New Brunswick. This brings the total number of Tachyporinae known from the province to 70. Lordithon campbelli Schülke is newly recorded for Canada and we provide the first documented records of Tachinus addendus Horn and Tachinus frigidus Erichson for New Brunswick. Collection and habitat data are presented and discussed for each species. A list of Tachyporinae species currently known from the province of New Brunswick is presented.
\end{abstract}

\section{Keywords}

Staphylinidae, Tachyporinae, new records, Canada, New Brunswick

\section{Introduction}

Intensive collecting of rove beetles (family Staphylinidae) in New Brunswick by the first author since 2003 and records from by-catch samples obtained during a study to develop a general attractant for the detection of invasive species of Cerambycidae have yielded many new provincial and national records. These are being published in a series of papers, each focusing on one or more subfamilies. This paper treats the subfamily Tachyporinae. The Tachyporinae of Canada and North America are fairly well known taxonomically thanks to various revisions by J.M. Campbell; Tachinus 
(Campbell 1973, 1975b, 1988), Coproporus and Cilea (Campbell 1975a), Sepedophilus (Campbell 1976), Tachyporus (Campbell 1979), Carphacis (Campbell 1980), Lordithon (Campbell 1982), Mycetoporus and Ischnosoma (Campbell 1991), Nitidotachinus (Campbell 1993a), and Bryoporus and Bryophacis (Campbell 1993b).

Tachyporinae can be found in a wide variety of habitats. Tachinus species are often found in decaying organic materials such as dung, rotting mushrooms, carrion, and compost, although some species are found in leaf litter and moist debris near streams, e.g., Tachinus limbatus Melsheimer (Campbell 1973). Nitidotachinus species are usually found in leaf litter or moss near streams, often in cool, shaded sites (Campbell 1993a). Tachyporus, Mycetoporus, Bryoporus, Bryophacis, and Ischnosoma species are usually associated with various kinds of litter and moss in forests and various wetland types, depending on the species (Campbell 1979, 1991, 1993b). Tachyporus species are often swept from vegetation in fields and other open habitats (Campbell 1979). Larvae and adults of Lordithon are associated with mushrooms and are active predators of Diptera larvae (Campbell 1982). Some Sepedophilus species are found in rotting wood, under loose bark, and in decaying and often moldy organic materials, such as rotting leaves (Campbell 1976); others are associated with polypore fungi or fleshy fungi on trees, depending on the species (Newton et al. 2000). Some species may be mycetophagous (Newton et al. 2000). Our only Coproporus species is subcortical (Campbell 1975b). However, in general, little is known about the biology of our North American Tachyporinae.

Thirty-six species of Tachyporinae were reported from New Brunswick by Campbell and Davies (1991). Nine species were added to the faunal list in revisions by Campbell (1991, 1993a, b) and from general surveys by Klimaszewski et al. (2005) and Majka and Klimaszewski (2008). Majka et al. (2011) reported Tachinus addendus Horn and Tachinus frigidus Erichson as occurring in New Brunswick but did provide any supporting references or data for the records. Here, we report an additional 23 species, bringing the total number of Tachyporinae known from New Brunswick to 70.

\section{Methods and conventions}

The following records are based on specimens collected as part of a general survey by the first author to document the Coleoptera fauna of New Brunswick and from bycatch samples obtained during a study to develop a general attractant for the detection of invasive species of Cerambycidae.

\section{Collection methods}

Various collection methods were employed to collect the Tachyporinae reported in this study. Details are outlined in Campbell (1973) and Webster et al. (2009, Appendix). See Webster et al. (2012) for details of the methods used for deployment of Lindgren 12-funnel traps and sample collection. A description of the habitat was recorded for all 
specimens collected during this survey. Locality and habitat data are presented exactly as on labels for each record. This information, as well as additional collecting notes, is summarized and discussed in the collection and habitat data section for each species.

\section{Specimen preparation}

Examples of males of most species were dissected to confirm their identity. The genital structures were dehydrated in absolute alcohol and mounted in Canada balsam on celluloid microslides and pinned with the specimens from which they originated.

\section{Distribution}

Distribution maps, created using ArcMap and ArcGIS, are presented for each species in New Brunswick. Every species is cited with current distribution in Canada and Alaska, using abbreviations for the state, provinces, and territories. New provincial records are indicated in bold under Distribution in Canada and Alaska. The following abbreviations are used in the text:

\begin{tabular}{ll|ll}
\hline AK & Alaska & MB & Manitoba \\
\hline YT & Yukon Territory & ON & Ontario \\
\hline NT & Northwest Territories & QC & Quebec \\
\hline NU & Nunavut & NB & New Brunswick \\
\hline BC & British Columbia & PE & Prince Edward Island \\
\hline AB & Alberta & NS & Nova Scotia \\
\hline SK & Saskatchewan & NF \& LB & Newfoundland and Labrador* \\
\hline
\end{tabular}

* Newfoundland and Labrador are each treated separately under the current Distribution in Canada and Alaska.

Acronyms of collections examined and referred to in this study are as follows:

AFC Atlantic Forestry Centre, Natural Resources Canada, Canadian Forest Service, Fredericton, New Brunswick, Canada

CNC Canadian National Collection of Insects, Arachnids and Nematodes, Agriculture and Agri-Food Canada, Ottawa, Ontario

NBM New Brunswick Museum, Saint John, New Brunswick, Canada

RWC Reginald P. Webster Collection, Charters Settlement, New Brunswick, Canada

\section{Results}

Twenty-three species of Tachyporinae are newly recorded from New Brunswick. Twelve of these are newly recorded from the Maritime provinces (New Brunswick, Nova Sco- 
tia, Prince Edward Island) of Canada, including Lordithon campbelli Schülke, which is newly recorded for Canada. The first documented records of T. addendus and T. frigidus from New Brunswick are provided. This brings the total number of species known from New Brunswick to 70 (Table 1).

Table I. Species of Tachyporinae (Staphylinidae) recorded from New Brunswick, Canada.

\begin{tabular}{|c|}
\hline Subfamily Tachyporinae MacLeay \\
\hline Tribe Tachyporini MacLeay \\
\hline Cilea silphoides (Linnaeus) \\
\hline Coproporus ventriculus (Say) \\
\hline $\begin{array}{l}\text { Nitidotachinus scrutator (Gemminger \& } \\
\text { Harold) }\end{array}$ \\
\hline Nitidotachinus tachyporoides (Horn) \\
\hline Nitidotachinus horni (Campbell)* \\
\hline Sepedophilus cinctulus (Erichson)* \\
\hline Sepedophilus crassus (Gravenhorst)* \\
\hline Sepedophilus littoreus (Linnaeus) \\
\hline Sepedophilus marshami (Stephens) \\
\hline Sepedophilus occultus Casey** \\
\hline Sepedophilus testaceus (Fabricius) \\
\hline Sepedophilus versicolor (Casey)** \\
\hline Tachinus addendus Horn \\
\hline Tachinus basalis Erichson \\
\hline Tachinus canadensis Horn** \\
\hline Tachinus corticinus Gravenhorst \\
\hline Tachinus fimbriatus Gravenhorst* \\
\hline Tachinus fumipennis (Say) \\
\hline Tachinus Limbatus Melsheimer \\
\hline Tachinus luridus Erichson \\
\hline Tachinus frigidus Erichson \\
\hline Tachinus memnonius Gravenhorst \\
\hline Tachinus picipes Erichson \\
\hline Tachinus quebecensis Robert \\
\hline Tachinus rufipes (DeGeer) \\
\hline Tachinus schwarzi Horn* \\
\hline Tachinus vergatus Campbell** \\
\hline Tachinus thruppi Hatch \\
\hline Tachyporus abdominalis (Fabricius) \\
\hline Tachyporus browni Campbell \\
\hline Tachyporus canadensis Campbell \\
\hline Tachyporus dispar (Paykull) \\
\hline Tachyporus flavipennis Campbell \\
\hline Tachyporus inornatus Campbell \\
\hline Tachyporus lecontei Campbell** \\
\hline
\end{tabular}

\begin{tabular}{|c|}
\hline Tachyporus maculicollis LeConte* \\
\hline Tachyporus nanus Erichson** \\
\hline Tachyporus nimbicola Campbell \\
\hline Tachyporus nitidulus (Fabricius) \\
\hline Tachyporus pulchrus Blatchley** \\
\hline Tachyporus rulomoides Campbell \\
\hline Tachyporus transversalis Gravenhorst** \\
\hline Tribe Mycetoporini Thomson \\
\hline Bryophacis smetanai Campbell \\
\hline Bryoporus rufescens LeConte \\
\hline Bryoporus testaceus LeConte \\
\hline Carphasis nepigonensis (Bernhauer) \\
\hline Ischnosoma fimbriatum Campbell \\
\hline Ischnosoma flavicolle (LeConte)** \\
\hline Ischnosoma pictum (Horn) \\
\hline Ischnosoma splendidum (Gravenhorst)* \\
\hline Ischnosoma virginicum (Bernhauer) \\
\hline Lordithon (Bolitobius) fungicola Campbell \\
\hline Lordithon (Bolitobius) kellyi Malkin \\
\hline Lordithon (Bolitobius) longiceps (LeConte)* \\
\hline Lordithon (Bolitobius) quaesitor (Horn)* \\
\hline Lordithon (Lordithon) anticus (Horn) \\
\hline Lordithon (Lordithon) appalachianus Campbell \\
\hline Lordithon (Lordithon) axillaris (Gravenhorst)** \\
\hline Lordithon (Lordithon) campbelli Schülke*** \\
\hline Lordithon (Lordithon) facilis (Casey) \\
\hline Lordithon (Lordithon) niger (Gravenhorst)** \\
\hline Lordithon (Lordithon) scutellaris Campbell \\
\hline $\begin{array}{l}\text { Lordithon (Lordithon) thoracicus thoracicus } \\
\text { (Fabricius) }\end{array}$ \\
\hline Mycetoporus americanus Erichson ${ }^{* *}$ \\
\hline Mycetoporus consors LeConte \\
\hline Mycetoporus horni (Bernhauer \& Schubert) \\
\hline Mycetoporus inquisitus Casey \\
\hline Mycetoporus lucidulus LeConte \\
\hline Mycetoporus rugosus Hatch* \\
\hline Mycetoporus triangulatus Campbell \\
\hline
\end{tabular}

Notes: ${ }^{*}$ New to province, ${ }^{* *}$ New to Maritime provinces, ${ }^{* * *}$ New to Canada. 


\section{Species accounts}

All species below are newly recorded for New Brunswick, Canada. Species followed by ** are newly recorded from the Maritime provinces; species followed by ${ }^{* * *}$ are newly recorded for Canada.

The classification of the Tachyporinae follows Bouchard et al. (2011).

Family Staphylinidae Latreille, 1802

Subfamily Tachyporinae MacLeay, 1825

Tribe Tachyporini MacLeay, 1825

Nitidotachinus horni Campbell, 1973

http://species-id.net/wiki/Nitidotachinus_horni

Map 1

Material examined. New Brunswick, Albert Co., Caledonia Gorge P.N.A. (Protected Natural Area), at Canada Creek, $45.7808^{\circ} \mathrm{N}, 64.7775^{\circ} \mathrm{W}, 4$.VII.2011, R. P. Webster, cold, clear, and shaded rocky brook in mixed forest, in saturated moss (1, NBM). Carleton Co., Jackson Falls, Bell Forest, $46.2208^{\circ} \mathrm{N}, 67.7231^{\circ} \mathrm{W}, 2 . \mathrm{VI} .2005$, R. P. Webster, mature hardwood forest, in litter on margin of cold spring-fed brook (1, RWC); Meduxnekeag Valley Nature Preserve, $46.1895^{\circ} \mathrm{N}, 67.6704^{\circ} \mathrm{W}, 13 . V I .2010$, 18.VI.2010, R. P. Webster, hardwood forest, margin of cold shaded spring-fed brook, under small rocks and in gravel (6, RWC).

Collection and habitat data. Adults of this rarely collected species were found in seepage areas, under stones on a stream margin, an alder thicket, and forest litter (Campbell 1988). In New Brunswick, adults were collected from under small rocks, in gravel, or in litter and moss along the margins of cold, shaded, spring-fed brooks in hardwood forests. Adults were collected during June and July.

Distribution in Canada and Alaska. ON, QC, NB, NS (Campbell 1973, 1988).

\section{Sepedophilus cinctulus (Erichson, 1839)}

http://species-id.net/wiki/Sepedophilus_cinctulus

Map 2

Material examined. New Brunswick, Albert Co., Caledonia Gorge P.N.A., $45.8257^{\circ} \mathrm{N}, 64.7791^{\circ} \mathrm{W}, 6$. VII.2011, R. P. Webster, old hardwood forest (sugar maple and beech), on Polyporus varius (1, NBM); Caledonia Gorge P.N.A., near Turtle Creek, $45.8380^{\circ} \mathrm{N}, 64.8484^{\circ} \mathrm{W}$, 3.VII.2011, A. Fairweather \& R. P. Webster, oldgrowth sugar maple and yellow birch forest, on Polyporus varius (1, NBM). Carleton Co., Richmond, near Hovey Hill P.N.A. (Protected Natural Area), $46.1155^{\circ} \mathrm{N}$, $67.7631^{\circ} \mathrm{W}, 24$. V.2005, R. P. Webster, clear-cut, in well rotted log (1, NBM); Jack- 
son Falls, Bell Forest, $46.2200^{\circ} \mathrm{N}, 67.7231^{\circ} \mathrm{W}, 16 . \mathrm{IX} .2006$, R. P. Webster, mature hardwood forest, on fleshy polypore fungi on beech $\log (8 \hat{\sigma}, 7$ q, NBM, RWC); same locality and forest type, 23-28.IV.2009, 14-20.V.2009, 20-26.V.2009, 8-16. VI.2009, R. Webster, V. Webster, \& M.-A. Giguère, Lindgren funnel traps (4, AFC). Queens Co., near Queenstown, $45.6904^{\circ} \mathrm{N}, 66.1455^{\circ} \mathrm{W}, 13 . V .2008$, R. P. Webster, old growth hardwood forest, under bark of sugar maple (1, NBM); Cranberry Lake P.N.A., $46.1125^{\circ} \mathrm{N}, 65.6075^{\circ} \mathrm{W}, 5-12 . V .2009,10-15 . V I I .2009$, R. Webster \& M.A. Giguère, mature red oak forest, Lindgren funnel traps (2, AFC, RWC). Sunbury Co., Acadia Research Forest, $46.0188^{\circ} \mathrm{N}, 66.3765^{\circ} \mathrm{W}, 17$. VIII.2007, R. P. Webster, mature red spruce and red maple forest, in Piptoporus betulinus (birch polypore) (1, AFC); Acadia Research Forest, $45.9866^{\circ} \mathrm{N}, 66.3841^{\circ} \mathrm{W}, 19-25 . V .2009$, R. Webster $\&$ M.-A. Giguère, mature (110 year-old) red spruce forest with scattered red maple and balsam fir, Lindgren funnel trap (1, AFC). York Co., $15 \mathrm{~km}$ W of Tracy off Rt. $645,45.6848^{\circ} \mathrm{N}, 66.8821^{\circ} \mathrm{W}, 9 . \mathrm{V} .2007$, R. P. Webster, old red pine forest, under bark of $\log (1, \mathrm{NBM})$; same locality and forest type but 11-19.V.2009, 19-25.V.2009, R. Webster \& M.-A. Giguère, Lindgren funnel traps (2, AFC); $14 \mathrm{~km}$ WSW of Tracy, S of Rt. $645,45.6741^{\circ} \mathrm{N}, 66.8661^{\circ} \mathrm{W}, 26 . \mathrm{IV}-10 . V .2009$, R. Webster \& C. MacKay, old mixed forest with red and white spruce, red and white pine, balsam fir, eastern white cedar, red maple, and Populus sp., Lindgren funnel trap (1, AFC).

Collection and habitat data. Campbell (1976) reported that most specimens of this species were collected from under bark. Others were found in mushrooms, Polyporus betulinus (Bull.) Fr., on dead logs, dead beech (Fagus grandifolia Ehrh.), and tree trunks and in tree holes. In New Brunswick, specimens were found on fleshy polypore fungi on a beech log, in Piptoporus betulinus (Bull.) P. Karst. (birch polypore), on Polyporus varius Fr., and in a well-rotted log. This species was commonly collected in Lindgren funnel traps in various forest types; mature hardwood forests with sugar maple (Acer saccharum Marsh.) and beech, old red oak (Quercus rubra L.) forest, old-growth hardwood forest with sugar maple and yellow birch (Betula alleghaniensis Britt.), 110-year-old red spruce (Picea rubens Sarg.) forest with red maple (Acer rubrum L.), old red pine (Pinus resinosa Ait.) forest, and an old mixed forest. Adults were collected during April, May, June, July, August, and September.

Distribution in Canada and Alaska. ON, QC, NB, NS (Campbell 1976; Bishop et al. 2009).

\section{Sepedophilus crassus (Gravenhorst, 1802)}

http://species-id.net/wiki/Sepedophilus_crassus

Map 3

Material examined. New Brunswick, Albert Co., Caledonia Gorge P.N.A., $45.8257^{\circ} \mathrm{N}, 64.7791^{\circ} \mathrm{W}, 6$. VII.2011, R. P. Webster, old hardwood forest (sugar maple and beech), on Polyporus varius (2, NBM). Carleton Co., Meduxnekeag Valley Nature Preserve, $46.1907^{\circ} \mathrm{N}, 67.6740^{\circ} \mathrm{W}$, 4.VIII.2006, 8.VIII.2006, R. P. Webster, hardwood 
forest, in fleshy polypore fungi on side of $\log (2, \mathrm{NBM})$; Jackson Falls, Bell Forest, $46.2200^{\circ} \mathrm{N}, 67.7231^{\circ} \mathrm{W}, 16 . \mathrm{IX} .2006$, R. P. Webster, mature hardwood forest, on fleshy polypore fungi on beech $\log (1 \hat{\jmath}$, RWC); same locality, collector and forest type, 7.VI.2007, in polypore fungi on large basswood $\log (1, \mathrm{NBM})$; same locality and forest type, 31.VII-7.VIII.2009, 7-12.VIII.2009, R. Webster \& M.-A. Giguère, Lindgren funnel traps (2, AFC). Sunbury Co., Acadia Research Forest, $45.9866^{\circ} \mathrm{N}, 66.3841^{\circ} \mathrm{W}$, 30.VI-8.VII.2009, 4-11.VIII.2009, R. Webster \& M.-A. Giguère, mature (110 yearold) red spruce forest with scattered red maple and balsam fir, Lindgren funnel traps (2, AFC). York Co., Fredericton, Odell Park, $45.9570^{\circ} \mathrm{N}, 66.6695^{\circ} \mathrm{W}, 19 . \mathrm{VI} .2005$, R. P. Webster, old growth hemlock forest, on bracket fungi ( 6 đ , 6 9, NBM, RWC); Charters Settlement, $45.8286^{\circ} \mathrm{N}, 66.7365^{\circ} \mathrm{W}, 15 . \mathrm{IX} .2006$, R. P. Webster, mature mixed forest, in polypore fungi on dead (standing) spruce ( 1 , RWC).

Collection and habitat data. Campbell (1976) reported that adults were frequently collected from rotten wood, from deep layers of decaying leaves, and from bracket fungi and mushrooms. Most specimens from New Brunswick were collected from fleshy polypore fungi and bracket fungi on standing dead trees and logs. Some adults were also collected from Lindgren funnel trap samples. Two specimens were collected from Polyporus varius Fr. on a rotten log. This species was found in sugar maple and beech forests, a red spruce forest, an old-growth hemlock (Tsuga canadensis (L.)) forest, and mixed forests. Adults were collected during June, July, August, and September.

Distribution in Canada and Alaska. ON, QC, NB, NS (Campbell 1976; Bishop et al. 2009).

\section{Sepedophilus occultus (Casey, 1884)**}

http://species-id.net/wiki/Sepedophilus_occultus

Map 4

Material examined. CANADA, New Brunswick, Gloucester Co., near Black Rock, $47.7411^{\circ} \mathrm{N}, 65.2577^{\circ} \mathrm{W}, 8 . \mathrm{VI} .2006$, R. P. Webster, old growth eastern white cedar swamp, inside well rotted fungus covered $\log (5 \hat{\sigma}, 4$, NBM, RWC). York Co. Charters Settlement, $45.8395^{\circ} \mathrm{N}, 66.7391^{\circ} \mathrm{W}, 22$.VIII.2005, R. P. Webster, mixed forest, in well rotted fungus covered $\log (1 \hat{\sigma}, \mathrm{NBM})$; same locality and collector but $45.8286^{\circ} \mathrm{N}, 66.7365^{\circ} \mathrm{W}, 24$.VI.2006, mature mixed forest, in polypore fungi on dead standing Populus sp. (1 0 , RWC).

Collection and habitat data. In the United States, this species has been collected from under bark, under a brush pile, and by sifting humus (Campbell 1976). The New Brunswick specimens were collected from the inside of well-rotted, fungus-covered logs and from polypore fungi on dead, standing Populus sp. This species was found in an old-growth eastern white cedar (Thuja occidentalis L.) swamp and in mature to old mixed forests. Adults were collected during June and August.

Distribution in Canada and Alaska. ON, QC, NB (Paquin and Dupérré 2001; Brunke and Marshall 2011). 
Sepedophilus versicolor (Casey, 1884)**

http://species-id.net/wiki/Sepedophilus_versicolor

Map 5

Material examined. CANADA, New Brunswick, Queens Co., Grand Lake near Scotchtown, $45.8762^{\circ} \mathrm{N}, 66.1816^{\circ} \mathrm{W}, 25 . \mathrm{V} .2006$, R. P. Webster, oak and maple forest, under bark of red oak (1 $9, \mathrm{RWC})$; same locality, forest type and collector, 19.IX.2006, on fleshy polypore fungi (1 Oे $^{2} 2$ क , RWC); Grand Lake Meadows P.N.A., $45.8227^{\circ} \mathrm{N}, 66.1209^{\circ} \mathrm{W}, 15-29 . V I .2010$, R. Webster \& C. MacKay, old silver maple forest with green ash and seasonally flooded marsh, Lindgren funnel trap (1, AFC); same locality data and forest type, 5-17.VIII.2011, 17-30.VIII.2011, M. Roy \& V. Webster, Lindgren funnel traps (2, AFC, NBM). Sunbury Co., Burton, near Sunpoke Lake, $45.7665^{\circ} \mathrm{N}, 66.5545^{\circ} \mathrm{W}, 15$. V.2004, R. P. Webster, red oak and red maple forest with scattered white pine, under bark (1 9 , RWC); Lakeville Corner, $45.9007^{\circ} \mathrm{N}$, $66.2423^{\circ} \mathrm{W}, 27$. VIII.2006, R. P. Webster, silver maple swamp, on polypore fungi on Populus sp. $\log \left(2{ }^{\top}\right.$, RWC). York Co., Charters Settlement, $45.8395^{\circ} \mathrm{N}, 66.7391^{\circ} \mathrm{W}$, 5.IX.2006, R. P. Webster, mixed forest, among decaying (moldy) corncobs and cornhusks ( 1 q, RWC).

Collection and habitat data. Campbell (1976) reported this species from mushrooms. In New Brunswick, specimens were collected from polypore fungi on logs, from under bark, and among moldy corncobs and cornhusks. This species was found in red oak and red maple forests, old silver maple (Acer saccharinum L.) forests, and near a mixed forest. Adults were collected during May, August, and September.

Distribution in Canada and Alaska. ON, NB. (Brunke and Marshall 2011). Campbell (1976) did not report this species from Canada. However, there are two specimens of this species in the Canadian National Collection from Turkey Point, Ontario collected in 1975 that first establish this species as a member of the Canadian fauna. Brunke and Marshall (2011) reported an additional record from Rondeau Provincial Park, Ontario. In the United States, this species occurs from New Hampshire west to Iowa and south to Florida (Campbell 1976).

\section{Tachinus addendus Horn, 1877}

http://species-id.net/wiki/Tachinus_addendus

Map 6

Material examined. Additional New Brunswick records, Albert Co., Shepody N.W.A., Mary's Point Section, $45.7260^{\circ}$ N, $64.6640^{\circ} \mathrm{W}, 12$. IX.2004, R. P. Webster, spruce forest, in decaying fleshy fungi $(1, \mathrm{RWC})$; Caledonia Gorge P.N.A., near Turtle Creek, $45.8380^{\circ} \mathrm{N}, 64.8484^{\circ} \mathrm{W}, 3$.VII.2011, R. P. Webster, old-growth sugar maple and yellow birch forest, in moose dung $(1, \mathrm{NBM})$. Carleton Co., Meduxnekeag River Valley Nature Preserve, $46.1907^{\circ} \mathrm{N}, 67.6740^{\circ} \mathrm{W}, 23 . V I .2006$, 7.IX.2004, R. P. Webster, mature hardwood forest, in rotting mushrooms (8, NBM, RWC); Two Mile Brook Fen, 


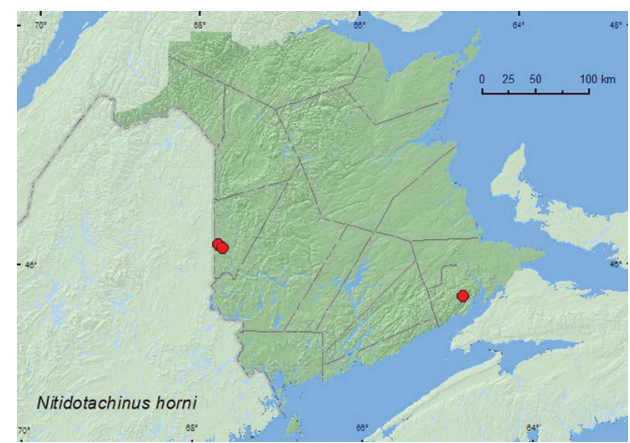

Map I. Collection localities in New Brunswick, Canada of Nitidotachinus horni.

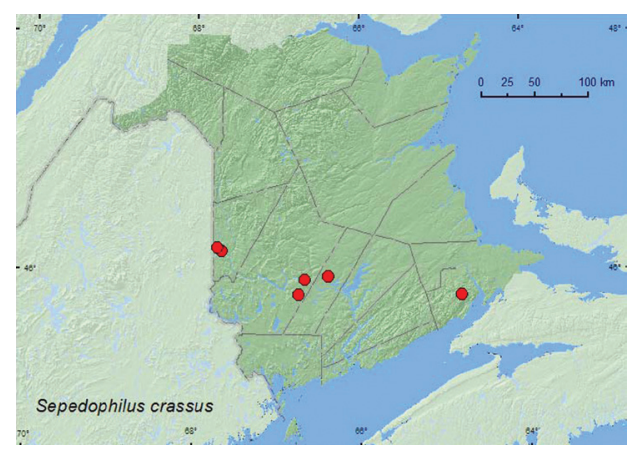

Map 3. Collection localities in New Brunswick, Canada of Sepedophilus crassus.

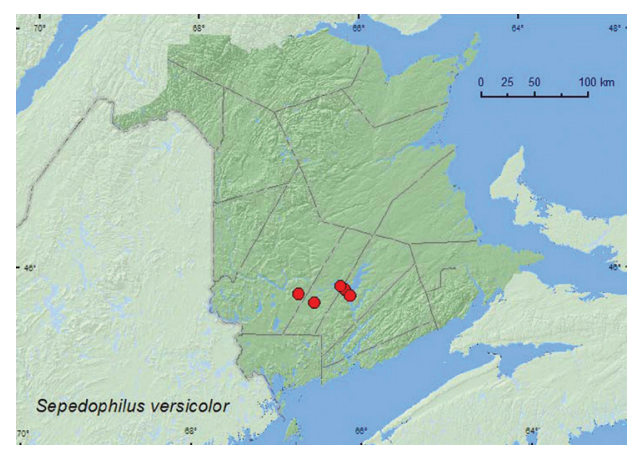

Map 5. Collection localities in New Brunswick, Canada of Sepedophilus versicolor.

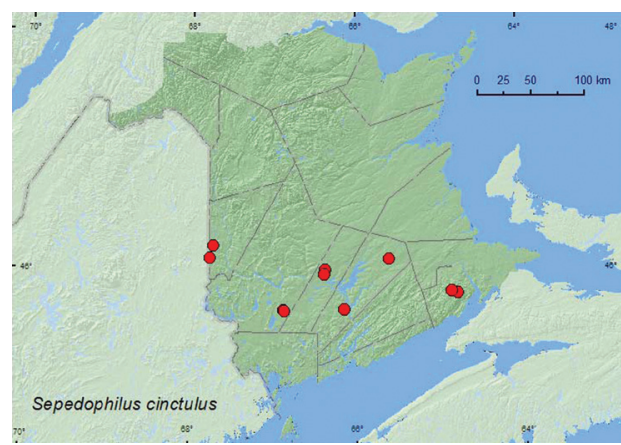

Map 2. Collection localities in New Brunswick, Canada of Sepedophilus cinctulus.

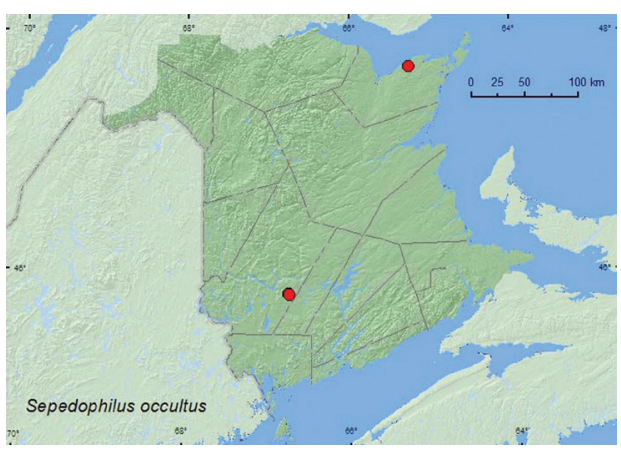

Map 4. Collection localities in New Brunswick, Canada of Sepedophilus occultus.

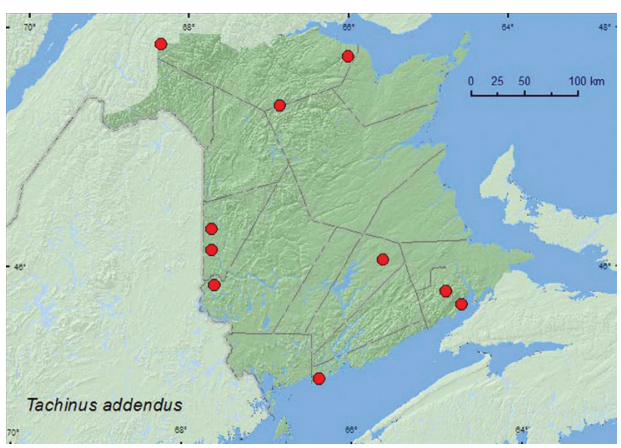

Map 6. Collection localities in New Brunswick, Canada of Tachinus addendus.

$46.3702^{\circ} \mathrm{N}, 67.6772^{\circ} \mathrm{W}, 4 . V I I I .2006$, R. P. Webster, mixed forest, in gilled mushroom (1, NBM). Queens Co., Cranberry Lake P.N.A, (Protected Natural Area) $46.1125^{\circ} \mathrm{N}$, $65.6075^{\circ} \mathrm{W}$, 2.IX.2009, R. Webster \& M.-A. Giguère, old red oak forest, in decaying gilled mushroom (1, AFC). Restigouche Co., Mount Carleton Provincial Park, Mt. Sagamook, $2000 \mathrm{ft}$. elev., $47.4112^{\circ} \mathrm{N}, 66.8599^{\circ} \mathrm{W}, 2 . I X .2006$, R. P. Webster, mixed for- 
est, in decaying gilled mushroom (1, NBM); Jacquet River Gorge P.N.A., $47.8160^{\circ} \mathrm{N}$, 66.0083 ${ }^{\circ} \mathrm{W}, 14$. VIII.2010, R. P. Webster, old eastern white cedar forest, in decaying mushrooms (1, NBM); Dionne Brook P.N.A., 47.9064 N, 68.3441 ${ }^{\circ} \mathrm{W}, 23 . \mathrm{VIII}-19$. IX.2011, M. Roy \& V. Webster, old-growth white spruce and balsam fir forest, Lindgren funnel trap (1, NBM). Saint John Co., Dipper Harbour, $45.1169^{\circ} \mathrm{N}, 66.3771^{\circ} \mathrm{W}$, 15.V.2006, R. P. Webster, upper margin of sea beach, in decaying sea wrack under alders (1, RWC). York Co., Browns Mountain Fen, 45.8965ํN, 67.6344 W, 5.VIII.2004, J. Edsall \& R. Webster, mixed forest, in decaying fleshy fungi (2, NBM, RWC).

Collection and habitat data. This species has been collected from dung, rotting mushrooms, deciduous leaf litter, and pine duff (Campbell 1973). Most adults from New Brunswick were collected from decaying mushrooms in hardwood and mixed forests. One individual was collected from decaying sea wrack under alders (Alnus sp.) on the upper margin of a sea beach, another was found in moose dung. Adults were collected during May, June, July, August, and September.

Distribution in Canada and Alaska. MB, ON, QC, NB, NS (Campbell 1973, 1988). Tachinus addendus was listed as occurring in New Brunswick by Majka et al. (2011) without any supporting references or data. Here, we provide the first documented records from New Brunswick.

\section{Tachinus canadensis Horn, 1877**}

http://species-id.net/wiki/Tachinus_canadensis

Map 7

Material examined. New Brunswick, Sunbury Co., Lakeville Corner, $45.9007^{\circ} \mathrm{N}$, $66.2423^{\circ} \mathrm{W}, 10 . \mathrm{IX} .2006$, R. P. Webster, silver maple forest on ridge with red oaks, on gilled mushrooms (2, RWC).

Collection and habitat data. Little was previously known about the habitat associations of this species other than some specimens having been collected from mushrooms (Campbell 1973). The two specimens from New Brunswick were collected from gilled mushrooms near a silver maple swamp during September. Campbell (1973) commented that the late period of annual activity (September and October) was quite different from other species occurring in eastern North America.

Distribution in Canada and Alaska. ON, QC, NB (Campbell 1973).

\section{Tachinus fimbriatus Gravenhorst, 1802}

http://species-id.net/wiki/Tachinus_fimbriatus

Map 8

Material examined. New Brunswick, Carleton Co., Hovey Hill P.N.A., $46.1115^{\circ} \mathrm{N}$, $67.7770^{\circ} \mathrm{W}, 7 . I X .2004$, R. P. Webster, mature mixed forest, in well rotted Boletus mushroom (2, RWC). 
Collection and habitat data. Tachinus fimbriatus is usually collected from rotting mushrooms (Campbell 1973), as were the two specimens from New Brunswick. Adults were collected in a mature mixed forest during September.

Distribution in Canada and Alaska. ON, QC, NB, NS (Campbell 1973, 1988).

\section{Tachinus frigidus Erichson, 1840}

http://species-id.net/wiki/Tachinus_frigidus

Map 9

Material examined. Additional New Brunswick records, Albert Co., Shepody N.W.A., Mary's Point Section, $45.7260^{\circ}$ N, $64.6640^{\circ}$ W, 12.IX.2004, R. P. Webster, spruce forest, in decaying fleshy fungi (gilled mushroom) (1, RWC).

Collection and habitat data. Campbell $(1973,1988)$ reported that most specimens of this northern transcontinental species were collected from under animal dung or decaying mushrooms. Adults were also collected from the mouth of animal burrows, in leaf litter and other kinds of decaying organic matter. In Alberta, T. frigidus was considered to be a mature forest (conifer-dominated) specialist (Pohl et al. (2007). The only specimen from New Brunswick was collected from a decaying fleshy mushroom during September in a mature, coastal red spruce forest.

Distribution in Canada and Alaska. AK, YT, NT, BC, AB, MB, ON, QC, NB, NS, LB (Campbell 1973). Tachinus frigidus was listed as occurring in New Brunswick by Majka et al. (2011) without any supporting references or data. Here we provide the first documented records from New Brunswick.

\section{Tachinus schwarzi Horn, 1877}

http://species-id.net/wiki/Tachinus_schwarzi

Map 10

Material examined. New Brunswick, Sunbury Co., Acadia Research Forest, $46.0188^{\circ} \mathrm{N}, 66.3796^{\circ} \mathrm{W}, 17$. VIII.2007, R. P. Webster, mature red spruce and red maple forest, in decaying fleshy polypore fungi on standing dead spruce ( $1 \hat{\mathrm{O}}$, AFC). Restigouche Co., vic. Summit Depot, $47.7836^{\circ} \mathrm{N}, 68.3227^{\circ} \mathrm{W}, 21$. VII.2010, M. Turgeon $\&$ R. Webster, clear-cut, on decaying Climacodon septentrionale on dead (standing) yellow birch (1, RWC); Dionne Brook P.N.A. $47.9030^{\circ} \mathrm{N}, 68.3503^{\circ} \mathrm{W}, 9 . \mathrm{VIII} .2011$, R. P. Webster, old-growth northern hardwood forest, on Climacodon septentrionale (Fr.) P. Karst. on sugar maple (2, RWC).

Collection and habitat data. Specimens of this species from New Brunswick were collected from a decaying fleshy polypore mushroom on a standing, dead spruce in a mature red spruce forest, from a decaying Climacodon septentrionale (Fr.) P. Karst. on a dead, standing yellow birch in a recent clearcut (boreal forest area), and from a (fresh) Climacodon septentrionale (Fr.) P. Karst. on a living sugar maple in an old-growth 
northern hardwood forest. Four individuals were collected in company with Lordithon niger (Gravenhorst) from a decaying fleshy polypore fungus on a standing, dead Populus sp. in a hardwood forest (sugar maple and American beech) in Saint-Raphaël (15.VII.2006), Quebec (Webster, unpublished). One specimen from Tennessee (USA) was sifted from leaf litter. Little was previously known about the habitat and biology of this rare species. Campbell (1973) suggested that this species lived in some restricted habitat, such as mammal burrows. The habitat data above suggest that this species may be associated with decaying fleshy polypore or polypore-like fungi on standing dead and living trees. Adults were collected during July and August.

Distribution in Canada and Alaska. QC, NB, NS (Campbell 1973, 1988).

\section{Tachinus vergatus Campbell, 1973**}

http://species-id.net/wiki/Tachinus_vergatus

Map 11

Material examined. New Brunswick, Queens Co., Cranberry Lake P.N.A, $46.1125^{\circ} \mathrm{N}$, 65.6075 ${ }^{\circ}$ W, 21-28.VII.2009, 2.IX.2009, R. Webster \& M.-A. Giguère, old red oak forest, Lindgren funnel traps (2, RWC). Restigouche Co., Dionne Brook P.N.A. $47.9030^{\circ} \mathrm{N}$, $68.3503^{\circ} \mathrm{W}, 14-28 . \mathrm{VII} .2011, \mathrm{M}$. Roy \& V. Webster, old-growth northern hardwood forest, Lindgren funnel trap (1, RWC); same locality and collectors but $47.9064^{\circ} \mathrm{N}$, $68.3441^{\circ} \mathrm{W}, 31 . \mathrm{V}-15 . V I .2011$, M. Roy \& V. Webster, old-growth white spruce and balsam fir forest, Lindgren funnel trap (1, RWC). Sunbury Co., Burton, SW of Sunpoke Lake, $45.7575^{\circ} \mathrm{N}, 66.5736^{\circ} \mathrm{W}, 16 . \mathrm{IV} .2005$, R. P. Webster, red maple swamp, in leaf litter near margin of slow stream (1, RWC). York Co. Charters Settlement, $45.8340^{\circ} \mathrm{N}, 66.7450^{\circ} \mathrm{W}$, 22.IV.2005, R. P. Webster, mature mixed forest, in wood pile under bark of spruce (3, RWC); same locality, collector and forest type but $45.8395^{\circ} \mathrm{N}, 66.7391^{\circ} \mathrm{W}, 23 . \mathrm{IV} .2008$, mixed forest, in flight, collected with net between 15:00 and 18:00h (1, RWC); $15 \mathrm{~km}$ W of Tracy off Rt. 645, 45.6848 N, 66.8821 ${ }^{\circ} \mathrm{W}, 22-25 . I V .2009,4-11 . V I I I .2009$, R. Webster and M.-A. Giguère, old red pine forest, Lindgren funnel traps (2, AFC, RWC).

Collection and habitat data. Little is known about the habitat associations of this species. Two adults of this rare species were collected from deciduous leaf litter along a small stream and from alder litter on a lake margin (Campbell 1975b). Others were taken from flight intercept traps (Campbell 1988). In New Brunswick, adults were collected from under bark in a wood pile, from leaf litter near a stream, and with a net during an evening flight. Some individuals were collected in Lindgren funnel traps deployed in old red oak forest, an old-growth red pine forest, an old-growth white spruce and balsam fir forest, and an old-growth northern hardwood forest. Adults were collected during April, June, July, August, and September but most during April.

Distribution in Canada and Alaska. AB, ON, QC, NB (Campbell 1973, 1975b, 1988; Pohl et al. 2007). 


\section{Tachyporus lecontei Campbell, 1991**}

http://species-id.net/wiki/Tachyporus_lecontei

Map 12

Material examined. New Brunswick, Queens Co., just W of Jemseg at "Trout Creek", $45.8227^{\circ} \mathrm{N}, 66.1240^{\circ} \mathrm{W}, 9 . V .2004$, R. P. Webster, silver maple swamp, sifting leaf litter at base of large tree (3, NBM); same locality, forest type, and collector but $45.8231^{\circ} \mathrm{N}, 66.1245^{\circ} \mathrm{W}$, 3.IV.2006, sifting litter from crotch of silver maple with multiple trunks (11, NBM, RWC); Grand Lake near Scotchtown, $45.8762^{\circ} \mathrm{N}$, $66.1816^{\circ} \mathrm{W}, 25 . I V .2004$, R. Webster \& M.-A. Giguère, oak/maple forest, under leaf litter at base of tree (1, NBM).

Collection and habitat data. Campbell (1991) reported this species from river banks, flood debris on rivers, under logs, and decaying vegetation. Most New Brunswick specimens were found in litter in crotches of silver maples with multiple trunks in an old silver maple swamp (floodplain forest) early in April. This habitat was probably an overwintering site for this species. Many other staphylinid adults of various species were found in the debris in these tree crotches. Other individuals were sifted from leaf litter at the bases of large silver maples. Adults were collected during April and May.

Distribution in Canada and Alaska. BC, AB, SK, MB, ON, QC, NB (Campbell 1991).

\section{Tachyporus maculicollis LeConte, 1866}

http://species-id.net/wiki/Tachyporus_maculicollis

Map 13

Material examined. New Brunswick, Carleton Co., Two Mile Brook Fen, $46.3594^{\circ} \mathrm{N}$, $67.6800^{\circ} \mathrm{W}, 2 . \mathrm{VI} .2005$, R. P. Webster, Carex marsh, treading Carex hummock into water (1, RWC); Jackson Falls, Bell Forest, $46.2208^{\circ} \mathrm{N}, 67.7231^{\circ} \mathrm{W}$ 19.IV.2006, R. P. Webster, mature hardwood forest, in litter and moss near brook (2, RWC); same locality, forest type, and collector, 12.IV.2007, in leaf litter at base of tree, $30-40 \mathrm{~cm}$ of snow still on ground, (2, RWC); Meduxnekeag Valley Nature Preserve, $46.1888^{\circ} \mathrm{N}, 67.6762^{\circ} \mathrm{W}$, 20.V.2005, M.-A. Giguère \& R. Webster, river margin in flood debris (1, RWC). Queens Co., just W of Jemseg at “Trout Creek", 45.8231 ${ }^{\circ} \mathrm{N}, 66.1245^{\circ} \mathrm{W}, 3 . I V .2006, \mathrm{R}$. P. Webster, silver maple swamp, sifting litter from crotch of silver maple with multiple trunks (1, RWC). Restigouche Co., near Little Tobique River, $47.4465^{\circ} \mathrm{N}, 67.0689^{\circ} \mathrm{W}$, 24.V.2007, R. P. Webster, river margin, in leaf litter under alders (1, RWC); Jacquet River Gorge P.N.A., at Jacquet River, $47.8257^{\circ} \mathrm{N}, 66.0779^{\circ} \mathrm{W}, 24 . V .2010$, R. P. Webster, partially shaded cobblestone bar near mouth of brook, under cobblestones and gravel on sand (1, NBM). York Co., Canterbury, near Browns Mountain Fen, $45.9033^{\circ} \mathrm{N}$, $67.6260^{\circ} \mathrm{W}, 2 . V .2005$, R. P. Webster, red maple swamp, vernal pond margin in leaf lit- 


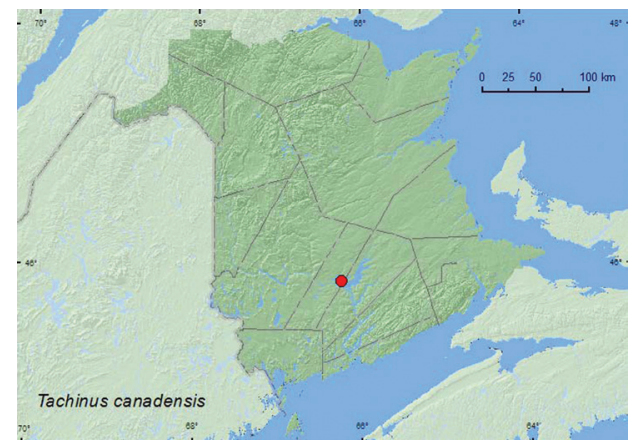

Map 7. Collection localities in New Brunswick, Canada of Tachinus canadensis.

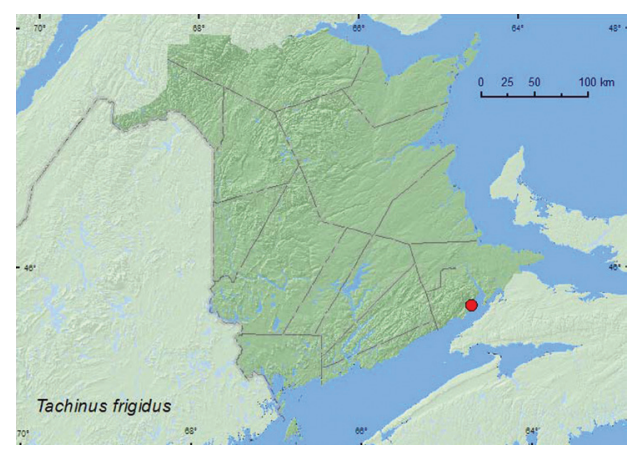

Map 9. Collection localities in New Brunswick, Canada of Tachinus frigidus.

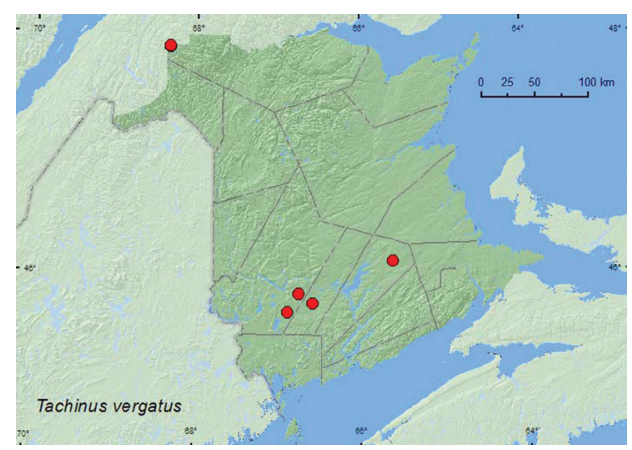

Map I I. Collection localities in New Brunswick, Canada of Tachinus vergatus.

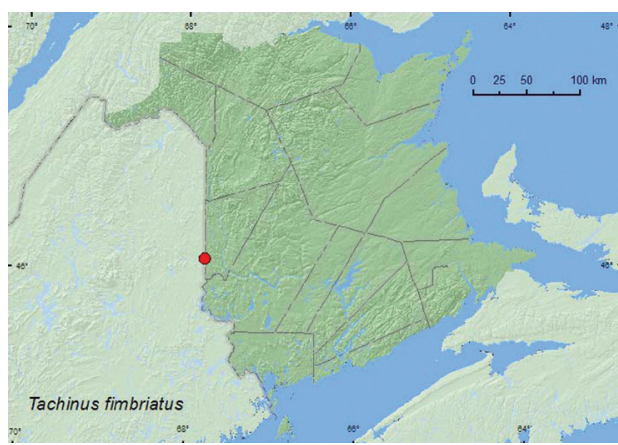

Map 8. Collection localities in New Brunswick, Canada of Tachinus fimbriatus.

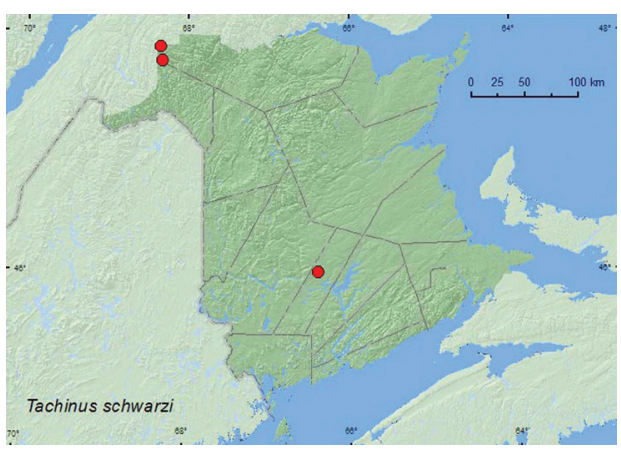

Map 10. Collection localities in New Brunswick, Canada of Tachinus schwarzi.

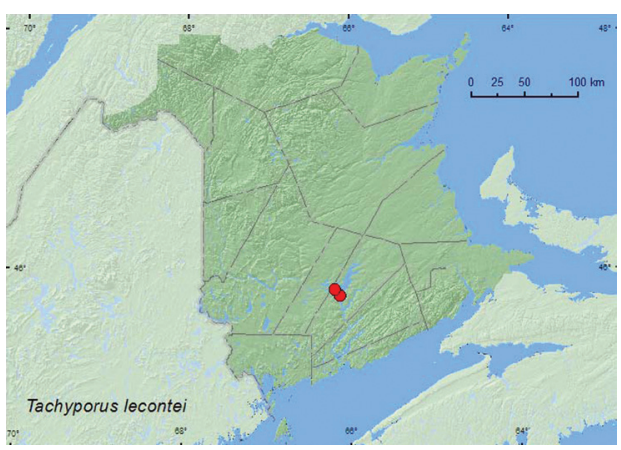

Map 12. Collection localities in New Brunswick, Canada of Tachinus lecontei.

ter (1, RWC); Charters Settlement, $45.8395^{\circ} \mathrm{N}, 66.7391^{\circ} \mathrm{W}$, 5.IX.2006, R. P. Webster, mixed forest, among decaying (moldy) corncobs and cornhusks (1, RWC).

Collection and habitat data. Campbell (1991) reported this species from a variety of habitats, including forest leaf litter, fungi on an old tree stump, among grass roots, damp moss near a pond, under a log on a lakeshore, and from Microtus pennsylvanicus 
(Ord) nests. In New Brunswick, specimens were found in a various microhabitats including leaf litter and moss near brooks, margins of vernal ponds and a river, leaf litter at bases of trees, and among decaying corncobs and cornhusks. This species was found in a Carex marsh, mature hardwood forests, silver maple swamps, mixed forests, and river and brook margins. Adults were collected during April, May, June, and September and were active early in the spring on bare patches around bases of trees when over $30 \mathrm{~cm}$ of snow was still on the ground.

Distribution in Canada and Alaska. BC, AB, SK, MB, ON, QC, NB, NS (Campbell 1979).

\section{Tachyporus nanus Erichson, 1839**}

http://species-id.net/wiki/Tachyporus_nanus

Map 14

Material examined. New Brunswick, Sunbury Co., Acadia Research Forest, $45.9866^{\circ} \mathrm{N}, 66.3841^{\circ} \mathrm{W}, 19-25 . V .2009$, R. Webster \& M.-A. Giguère, mature (110 year-old) red spruce forest with scattered red maple and balsam fir, Lindgren funnel traps (2 $\mathrm{O}^{\top}$, AFC, RWC). York Co., $15 \mathrm{~km} \mathrm{~W}$ of Tracy, off Rt. $645,45.6848^{\circ} \mathrm{N}$, $66.8821^{\circ} \mathrm{W}, 19-25 . V .2009$, R. Webster \& M.-A. Giguère, old (120-180 year-old) red

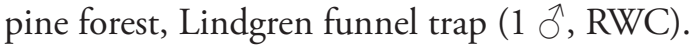

Collection and habitat data. This rare species has been collected from the fallen nest of a squirrel and a Berlese sample of decaying moldy material from the base of a tree (Campbell 1979). The three specimens from New Brunswick were captured in Lindgren funnel traps deployed in a 110-year-old red spruce forest and an old (120- to 180-year-old) red pine forest. Adults were collected during May.

Distribution in Canada and Alaska. ON, QC, NB (Campbell 1979).

\section{Tachyporus pulchrus Blatchley, 1910**}

http://species-id.net/wiki/Tachyporus_pulchrus

Map 15

Material examined. New Brunswick, Charlotte Co., $3.5 \mathrm{~km}$ NW of Pomeroy Ridge, $45.3087^{\circ} \mathrm{N}, 67.4362^{\circ} \mathrm{W}, 16 . \mathrm{VI} .2008$, R. P. Webster, red maple swamp, in leaves and moss near small vernal pool (1, RWC). Northumberland Co., Goodfellow Brook P.N.A., $46.8943^{\circ} \mathrm{N}, 65.3796^{\circ} \mathrm{W}, 23$. V.2007, R. P. Webster, old growth wet eastern white cedar swamp, in grass litter and moss on hummocks near pool (1 + , NBM). Sunbury Co., W of Sunpoke Lake, $45.7589^{\circ} \mathrm{N}, 66.5779^{\circ} \mathrm{W}, 22 . I V .2006$, R. P. Webster, red maple swamp, in moist leaves near vernal pool (1, NBM). York Co. Charters Settlement, $45.8267^{\circ} \mathrm{N}, 66.7343^{\circ} \mathrm{W}, 16 . I V .2005$, 9.IV.2006, 21.IV.2006, 23.V.2006, 14.IX.2006, R. P. Webster, Carex marsh/fen, in sphagnum hummocks (treading) and in leaf litter at bases of trees and shrubs (9, NBM, RWC); Mazerolle Settle- 
ment, $45.8729^{\circ} \mathrm{N}, 66.8311^{\circ} \mathrm{W}$, 9.IV.2006, R. P. Webster, stream margin, in litter at base of eastern white cedar (2, NBM, RWC); off Hwy 2, N of Hanwell, $45.8987^{\circ} \mathrm{N}$, $66.7903^{\circ} \mathrm{W}, 9 . \mathrm{IV} .2006, \mathrm{R}$. P. Webster, open grassy alder swamp, in grass litter (1, RWC); $9 \mathrm{~km} \mathrm{~W}$ of Tracy, $45.6888^{\circ} \mathrm{N}, 66.8004^{\circ} \mathrm{W}, 22 . \mathrm{V} .2008$, R. P. Webster, Carex marsh/flowage, treading Carex hummock (1, NBM).

Collection and habitat data. This uncommon species was reported from dead swamp grass, among leaves, from moss, and from an entrance to a Marmota burrow by Campbell (1979). In New Brunswick, T. pulchrus was found in various wetland habitats, including eastern white cedar swamps, red maple swamps, an open grassy alder swamp, a Carex marsh/fen, a Carex marsh/flowage, and a stream margin near an eastern white cedar swamp. Adults occurred in leaves and moss, grass litter and moss on hummocks, sphagnum hummocks, leaf litter at bases of trees, and in grass litter and were collected by sifting or treading. This species was collected during April, May, June, and September (most during April).

Distribution in Canada and Alaska. MB, ON, NB (Campbell 1979).

\section{Tachyporus transversalis Gravenhorst, 1806**}

http://species-id.net/wiki/Tachyporus_transversalis

Map 16

Material examined. New Brunswick, Carleton Co., Two Mile Brook Fen, $46.3619^{\circ} \mathrm{N}$, $67.6733^{\circ} \mathrm{W}, 6 . \mathrm{V} .2005$, R. P. Webster, eastern white cedar swamp, in litter at base of cedar (1, NBM); near Hovey Hill P.N.A., 46.1152 ${ }^{\circ} \mathrm{N}, 67.7632^{\circ} \mathrm{W}, 10 . \mathrm{V} .2005$, R. P. Webster, mixed forest with cedar, vernal pond margin, in moist leaves on muddy soil (4, RWC). Charlotte Co., Rt. 3 at Deadwater Brook, $45.4744^{\circ} \mathrm{N}, 67.1225^{\circ} \mathrm{W}$, 3.VI.2005, R. P. Webster, black spruce forest (forested bog) in moist sphagnum (1, RWC). Saint John Co., Musquash, 45.1856 N, 66.3402W, 30.V.2006, R. P. Webster, freshwater marsh, in litter on hummock (1, RWC). York Co., Charters Settlement, $45.8267^{\circ} \mathrm{N}, 66.7343^{\circ} \mathrm{W}, 16 . I X .2005$, 29.III.2006, R. P. Webster, sedge fen, in litter and moss at base of tree (2, NBM, RWC); Mazerolle Settlement, $45.8788^{\circ} \mathrm{N}$, $66.8311^{\circ} \mathrm{W}, 9 . I V .2006$, R. P. Webster, margin of stream in litter at base of cedar (1, RWC); $9 \mathrm{~km}$ W of Tracy off Rt. 645, $45.6888^{\circ} \mathrm{N}, 66.8004^{\circ} \mathrm{W}, 22 . \mathrm{V} .2008$, R. P. Webster, sedge marsh, in Carex hummock (3, NBM, RWC); New Maryland, U.N.B. Woodlot, $45.9116^{\circ} \mathrm{N}, 66.6698^{\circ} \mathrm{W}, 26 . V .2008$, R. Webster, G. Forbes, \& M.-A. Giguère, abandoned beaver lodge occupied by muskrats, in debris in roof of lodge (1, RWC).

Collection and habitat data. This is a hygrophilous species in both Europe and North America and is usually found in marshes and bogs in moss (especially sphagnum) and debris (Campbell 1991). In New Brunswick, this species was found in various wetland habitats, including a forested black spruce (Picea mariana (Mill.) B.S.P.) bog, an eastern white cedar swamp, sedge (Carex) fens and marshes, freshwater marshes, stream margins, the margin of a vernal pond, and in an abandoned North American beaver Castor canadensis Kuhl) lodge occupied by muskrats (Ondatra zibethicus L.). 
Adults occurred in moist leaves, sphagnum, litter, and moss, in Carex hummocks, and in debris in the roof of a beaver lodge. In New Brunswick, this species was collected during March, April, May, and June.

Distribution in Canada and Alaska. ON, QC, NB (Campbell 1991). Campbell (1991) considered the distribution and habitat of this species in the Nearctic region unusual for a Holarctic species because of the specialized habitat preferences (found in sphagnum and debris in marshes and bogs) and pattern of distribution (restricted to Ottawa Valley of Ontario and Quebec). He suggested that the species may have been overlooked by most collectors and may actually have a broader distribution in North America than the records indicate. Klimaszewski et al. (2010) considered Tachyporus transversalis Gravenhorst as an adventive Palaearctic species.

\section{Tribe Mycetoporini Thomson, 1859}

\section{Ischnosoma flavicolle (LeConte, 1863)**}

http://species-id.net/wiki/Ischnosoma_flavicolle

Map 17

Material examined. CANADA, New Brunswick, Carleton Co., Jackson Falls, Bell Forest, $46.2208^{\circ} \mathrm{N}, 67.7231^{\circ} \mathrm{W}, 19 . I V .2005$, R. P. Webster, mature hardwood forest, in moss and litter near stream (1, RWC). Charlotte Co., $3.0 \mathrm{~km} \mathrm{NW}$ of Pomeroy Ridge, $45.3059^{\circ} \mathrm{N}, 67.4343^{\circ} \mathrm{W}, 5 . V I .2008$, R. P. Webster, alder swamp, in moss hummocks with grasses (1, RWC). Queens Co., Upper Gagetown, bog adjacent to Hwy 2, 45.8316 ${ }^{\circ} \mathrm{N}, 66.2346^{\circ} \mathrm{W}, 12 . \mathrm{IV} .2006$, R. P. Webster, tamarack bog, in sphagnum hummock in open bog (2, NBM, RWC). Saint John Co., Chance Harbour, off Rt. $790,45.1355^{\circ} \mathrm{N}, 66.3672^{\circ} \mathrm{W}, 15$. V.2006, R. P. Webster, calcareous fen, in sphagnum and litter among Carex (1, RWC). Sunbury Co., Burton, SW of Sunpoke Lake, $45.7575^{\circ} \mathrm{N}, 66.5736^{\circ} \mathrm{W}, 10 . \mathrm{IV} .2005$, R. P. Webster, red maple swamp, in leaf litter at base of tree (1, RWC). York Co. Charters Settlement, $45.8267^{\circ} \mathrm{N}, 66.7343^{\circ} \mathrm{W}$, 9.IV.2005, 16.IV.2005, R. P. Webster, Carex marsh/fen, in sphagnum hummocks and litter at base of trees (6, NBM, RWC); same locality and collector but $45.8428^{\circ} \mathrm{N}$, $66.7279^{\circ} \mathrm{W}, 20 . \mathrm{IV} .2005$, small sedge marsh, in moist grass litter and sphagnum (1, RWC); $14 \mathrm{~km} \mathrm{WSW} \mathrm{of} \mathrm{Tracy,} \mathrm{S} \mathrm{of} \mathrm{Rt.} 645,45.6755^{\circ} \mathrm{N}, 66.8685^{\circ} \mathrm{W}, 4 . I X .2008$, R. P. Webster, red maple swamp with alders, sifting moist leaf litter and moss (1, NBM).

Collection and habitat data. Campbell (1991) reported that this species was often found in drier habitats than other members of the Pictum group of species. Adults were reported from various kinds of forest litter in pine, hardwood, and mixed pine and hardwood forests as well as cypress forests (Campbell 1991). In New Brunswick, this species was most often found in and near wetland habitats, such as calcareous fens, Carex marshes, tamarack (Larix laricina (Du Roi) Koch) bogs, alder swamps, and red maple swamps. One adult was found near a stream in a mature hardwood forest. Adults occurred in moss and sphagnum hummocks, moss, leaf and grass litter at bases 
of trees, and Carex hummocks. Adults were collected during April, May, June, and September.

Distribution in Canada and Alaska. ON, NB (Brunke and Marshall 2011). In the United States, I. flavicolle occurs throughout the southeast north to New Hampshire along the eastern seaboard (Campbell 1991).

\section{Ischnosoma splendidum (Gravenhorst, 1806)}

http://species-id.net/wiki/Ischnosoma_splendidum

Map 18

Material examined. New Brunswick, Carleton Co., Meduxnekeag River Valley Nature Preserve, $46.1907^{\circ} \mathrm{N}, 67.6740^{\circ} \mathrm{W}$, 7.IX.2004, R. P. Webster, small balsam fir stand (near hardwood stand), in fleshy gilled mushrooms (2, RWC); same locality, forest type and collector, 11.V.2005, in moldy conifer duff (4, RWC).

Collection and habitat data. Campbell (1991) reported this species from various of wetland habitats as well as forests. Adults were taken from flood debris along rivers, margins of beaver ponds, beaver lodges, muskrat nests, mallard (Anas platyrhynchos L.) nests, moss near seepage areas, leaf litter along margins of marshes, streams, and bogs, and various kinds of grass and leaf litter from conifer and deciduous forests (Campbell 1991). Recent studies in Alberta (mid-boreal ecoregion) by Buddle et al. (2006) indicated that this species was associated with old ( $>70$-year-old) fire-origin, mixed wood forest stands. Later, Pohl et al. (2007) reported that this species was also associated with regenerating mixed wood stands in the western foothills of Alberta. The specimens from New Brunswick were collected in moldy conifer duff and fleshy gilled mushrooms in a small balsam fir (Abies balsamea (L.) Mill.) (regenerating) stand adjacent to a hardwood forest. Campbell (1991) reported most specimens of this species were taken in June to September. The specimens from New Brunswick were collected during May and September.

Distribution in Canada and Alaska. AK, YT, NT, BC, AB, SK, MB, ON, QC, NB, NS, LB, NF (Campbell 1991).

\section{Lordithon (Bolitobus) longiceps (LeConte, 1863)}

http://species-id.net/wiki/Lordithon_longiceps

Map 19

Material examined. New Brunswick, Carleton Co., Jackson Falls, Bell Forest, $46.2200^{\circ} \mathrm{N}, 67.7231^{\circ} \mathrm{W}, 16 . \mathrm{IX} .2006$, R. P. Webster, mature hardwood forest, on Bjerkandera adusta (Willd.) P. Karsten on dead standing beech tree and on a beech log (2 o, 4 ㅇ, RWC); Meduxnekeag River Valley Nature Preserve, $46.1897^{\circ} \mathrm{N}, 67.6710^{\circ} \mathrm{W}$, 12.IX.2008, R. P. Webster, mixed forest, on mass of Pholiota sp. mushrooms at base of dead standing Populus sp. (1 $\hat{\partial}$, RWC). Restigouche, Co., Dionne Brook P.N.A., 


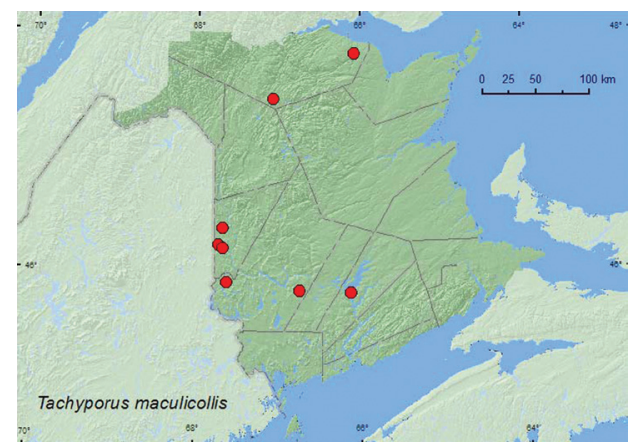

Map I3. Collection localities in New Brunswick, Canada of Tachinus maculicollis.

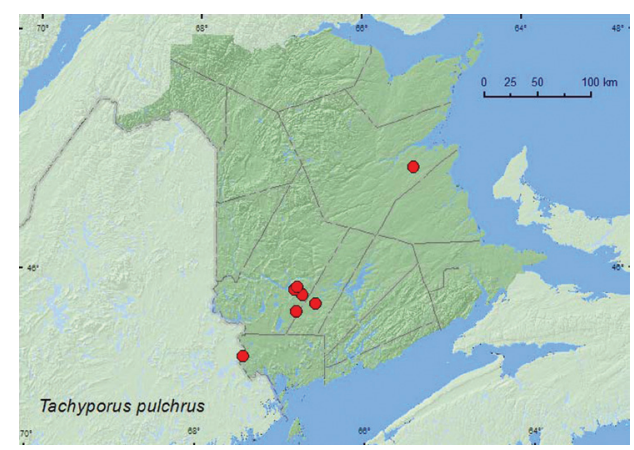

Map I5. Collection localities in New Brunswick, Canada of Tachinus pulchrus.

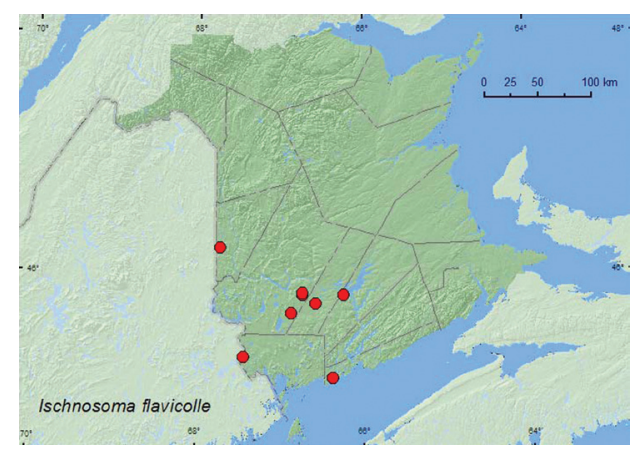

Map I7. Collection localities in New Brunswick, Canada of Ischnosoma flavicolle.

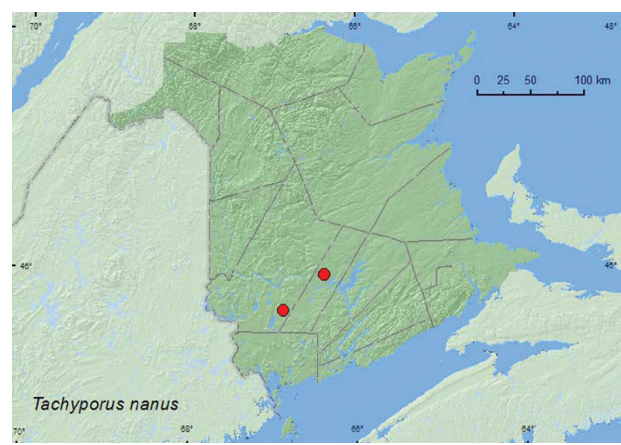

Map 14. Collection localities in New Brunswick, Canada of Tachinus nanus.

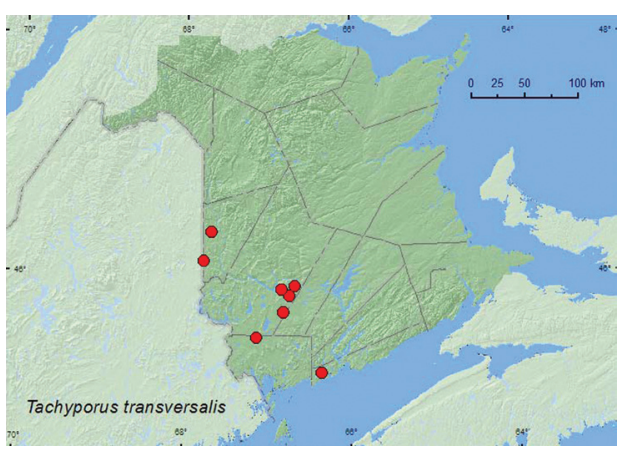

Map 16. Collection localities in New Brunswick, Canada of Tachinus transversalis.

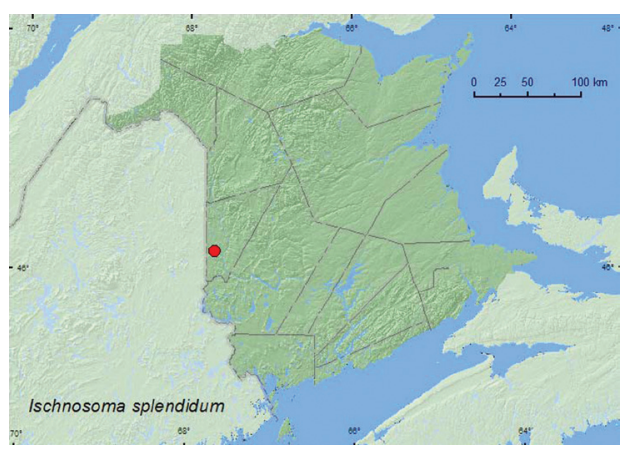

Map 18. Collection localities in New Brunswick, Canada of Ischnosoma splendidum.

$47.9064^{\circ} \mathrm{N}, 68.3441^{\circ} \mathrm{W}, 31 . V-15 . V I .2011, \mathrm{~K}$. Van Rooyen \& C. Hughes, old-growth white spruce and balsam fir forest, Lindgren funnel trap ( 1 \%, RWC).

Collection and habitat data. Little is known about the habitat requirements of this rare species. Campbell (1982) reported that adults have been taken on rotting 
gilled mushrooms. Most of the specimens from New Brunswick were collected from the fleshy polypore fungus, Bjerkandera adusta (Willd.) P. Karsten growing on a dead, standing American beech tree and a beech log. One individual was found in a mass of Pholiota sp. mushrooms at the base of a dead, standing Populus sp. Another individual was captured in a Lindgren funnel trap. Adults were found in mature hardwood and adjacent mixed forests, and in an old-growth white spruce and balsam fir forest. This species was collected during September in New Brunswick.

Distribution in Canada and Alaska. AK, BC, AB, ON, PQ, NB, NS (Campbell 1982; Campbell and Davies 1991). This northern species has a very broad distribution from Alaska to Nova Scotia, but with large distributional gaps between known localities (Campbell 1982).

\section{Lordithon (Bolitobus) quaesitor (Horn, 1877)} http://species-id.net/wiki/Lordithon_quaesitor Map 20

Material examined. New Brunswick, Albert Co., Caledonia Gorge P.N.A., near Turtle Creek, $45.8380^{\circ} \mathrm{N}, 64.8484^{\circ} \mathrm{W}, 3$. VII.2011, A. Fairweather \& R. P. Webster, oldgrowth sugar maple and yellow birch forest, on Polyporus varius (1 $\delta^{7}, 1$ q, RWC); same locality but $45.8415^{\circ} \mathrm{N}, 64.8467^{\circ} \mathrm{W}, 5 . V I I .2011$, R. P. Webster, old-growth sugar maple and yellow birch forest, on Polyporus varius on dead standing beech (1 o, NBM). Carleton Co., Meduxnekeag River Valley Nature Preserve, $46.1907^{\circ} \mathrm{N}$, $67.6740^{\circ} \mathrm{W}, 4 . V I I I .2006$, R. P. Webster, mature hardwood forest, in Bjerkandera adusta (Willd.) P. Karsten on side of beech $\log (1$,, $\mathrm{RWC})$; Meduxnekeag River Valley Nature Preserve, $46.1878^{\circ} \mathrm{N}, 67.6705^{\circ} \mathrm{W}$, 2.IX.2008, R. P. Webster, hardwood forest, in Bjerkandera adusta (Willd.) P. Karsten on side of beech log (2 +, NBM, RWC); same locality and collector, 2.IX.2008, hardwood forest, on Pleurotus sp. mushroom on side of $\log \left(1\right.$, NBM); Jackson Falls, Bell Forest, $46.2200^{\circ} \mathrm{N}, 67.7231^{\circ} \mathrm{W}, 16 . \mathrm{IX} .2006$, R. P. Webster, mature hardwood forest, on Bjerkandera adusta (Willd.) P. Karsten on dead standing beech tree and on beech $\log (3$, RWC). Restigouche Co., Dionne Brook P.N.A., $47.9030^{\circ} \mathrm{N}, 68.3503^{\circ} \mathrm{W}, 19 . \mathrm{IX} .2011$, R. P. Webster, old-growth northern hardwood forest, in gilled mushroom (1, RWC). Sunbury Co., Acadia Research Forest, $45.9866^{\circ} \mathrm{N}, 66.3841^{\circ} \mathrm{W}, 9-16 . V I .2009$, R. Webster \& M.-A. Giguère, mature (110 year-old) red spruce forest with scattered red maple and balsam fir, Lindgren funnel trap (1, AFC). York Co. Charters Settlement, $45.8340^{\circ} \mathrm{N}, 66.7450^{\circ} \mathrm{W}, 20 . V .2007$, R. P. Webster, mixed forest, in polypore fungi on Populus sp. $\log (1$ +, RWC); Kelly's Creek at Sears Rd., $45.8723^{\circ} \mathrm{N}, 66.8414^{\circ} \mathrm{W}, 8 . V I .2008$, R. P. Webster, alder swamp, on Pleurotus sp. on dead standing balsam poplar (1 9 , RWC).

Collection and habitat data. Little was previously known about the habitat associations of this rare species (Campbell 1982). In New Brunswick, adults of Lordithon quaesitor were most frequently found on Bjerkandera adusta (Willd.) P. Karsten (a fleshy polypore fungus) on the side of beech logs and standing dead beech trees in 
mature hardwood forests. This species was also found in Pleurotus sp., among a group of Polyporus varius Fr. on a large sugar maple log and on a dead standing American beech in an old-growth hardwood forest with sugar maple and yellow birch, in polypore fungi on sides of logs, in Pleurotus sp. on a dead standing balsam poplar (Populus balsamifera L.) tree, and in a gilled mushroom on the forest floor of an old-growth northern hardwood forest with sugar maple and yellow birch. One adult was collected in a Lindgren funnel trap. Some adults were collected in a mature red spruce forest, a mixed forest, and an alder swamp adjacent to a mixed forest. Lordithon quaesitor was sometimes found together with L. niger, L. axillaris, and L. longiceps and probably has a similar biology to those species. Adults were collected during May, June, July, August, and September.

Distribution in Canada and Alaska. ON, QC, NB, NS (Campbell 1976; Campbell and Davies 1991; Bishop et al. 2009).

\section{Lordithon (Lordithon) axillaris (Gravenhorst, 1806)** http://species-id.net/wiki/Lordithon_axillaris Map 21}

Material examined. New Brunswick, Carleton Co., Hovey Hill P.N.A., $46.1115^{\circ} \mathrm{N}$, 67.7770 ${ }^{\circ} \mathrm{W}, 19 . \mathrm{VIII} .2004$, R. P. Webster, mature hardwood forest, on Pleurotus sp. on side of $\log \left(1 \delta^{\jmath}, 1\right.$ ㅇ, RWC); Meduxnekeag River Valley Nature Preserve, $46.1940^{\circ} \mathrm{N}$, 67.6800², 23.VI.2006, 3.VII.2006, R. P. Webster, mixed forest, on Pleurotus sp on dead standing Populus sp. (2 $\sigma^{\lambda}$, RWC); Meduxnekeag River Valley Nature Preserve, $46.1878^{\circ} \mathrm{N}, 67.6705^{\circ} \mathrm{W}, 18$. VIII.2008, R. P. Webster, hardwood forest, in large (orange) gilled mushrooms near base of dead standing beech tree ( 2 ${ }^{\lambda}, 3$ q , RWC, NBM); same locality but $46.1887^{\circ} \mathrm{N}, 67.6735^{\circ} \mathrm{W}, 18 . V I .2010$, R. P. Webster, hardwood forest, in Laetiporus sulphureus (1, RWC).

Collection and habitat data. Little was previously known about the habitat associations of this rare species. One specimen from Quebec was collected from large gilled mushrooms on the side of a log (Campbell 1982). Four specimens of this species were collected from Pleurotus sp. mushrooms on the side of Populus logs in a hardwood forest in Saint-Raphaël (15.VII.2006), Quebec (Webster, unpublished). Most specimens from New Brunswick were collected from Pleurotus sp. mushrooms on standing dead Populus sp. trees or on the side of logs in mature hardwood forests with sugar maple and beech. Some adults were also collected from a large orange-gilled mushroom on the side of a log. One individual was collected from inside a Laetiporus sulphureus (Fr.) Murr. (Polyporaceae). These data suggest that this species may be specialized on Pleurotus sp. and other large gilled mushrooms that grow on standing dead trees or logs. Campbell (1982) suggested that this species, like L. niger and the European L. bicolor (Gravenhorst), may be associated with old-growth hardwood forests. Adults of L. axillaris were collected during June, July, and August in New Brunswick.

Distribution in Canada and Alaska. QC, NB (Campbell 1982). 
Lordithon (Lordithon) campbelli Schülke, 2000***

http://species-id.net/wiki/Lordithon_campbelli

Map 22

Material examined. CANADA, New Brunswick, Carleton Co., Meduxnekeag River Valley Nature Preserve, $46.1940^{\circ} \mathrm{N}, 67.6800^{\circ} \mathrm{W}, 23 . V I .2006$, R. P. Webster, mixed forest, on Pleurotus sp on dead standing Populus sp. (1 9 , RWC); Jackson Falls, Bell Forest, $46.2200^{\circ} \mathrm{N}, 67.7231^{\circ} \mathrm{W}, 19 . \mathrm{VII} .2006$, R. P. Webster, mature hardwood forest, in gilled mushroom (4 $0^{\wedge}, 3$ q, RWC).

Collection and habitat data. Campbell (1982) reported collecting adults from various gilled and pore mushroom species. In New Brunswick, adults were collected from gilled mushrooms on forest floor and on Pleurotus sp. on a dead, standing Populus sp. Adults were collected during June and July.

Distribution in Canada and Alaska. NB (first Canadian record). In the United States, this species (as L. angularis (Saches) in Campbell 1982) is distributed from Massachusetts to Florida, west to Missouri (Campbell 1982). This species probably occurs in intervening areas between Massachusetts and New Brunswick.

\section{Lordithon (Lordithon) niger (Gravenhorst, 1802)**}

http://species-id.net/wiki/Lordithon_niger

Map 23

Material examined. New Brunswick, Carleton Co., Meduxnekeag River Valley Nature Preserve, $46.1907^{\circ} \mathrm{N}, 67.6740^{\circ} \mathrm{W}, 4$.VIII.2006, R. P. Webster, mature hardwood forest, in Bjerkandera adusta (Willd.) P. Karsten (a fleshy polypore fungi) on side of beech $\log \left(1\right.$ \% RWC); Jackson Falls, Bell Forest, $46.2200^{\circ} \mathrm{N}, 67.7231^{\circ} \mathrm{W}$, 16.IX.2006, R. P. Webster, mature hardwood forest, in Bjerkandera adusta (Willd.) P. Karsten on dead standing beech tree (1 9 , RWC); same locality, collector, and forest type but 18.VIII.2008, in Porodaedalea sp. (fleshy polypore) on dead standing beech tree (1 $\widehat{\jmath}$, RWC). Queens Co., Cranberry Lake P.N.A, $46.1125^{\circ} \mathrm{N}, 65.6075^{\circ} \mathrm{W}$, 11-18.VI.2009, R. Webster \& M.-A. Giguère, old red oak forest, Lindgren funnel trap (1, AFC).

Collection and habitat data. Nothing was previously known about the habitat associations of this rare species (Campbell 1982). The New Brunswick specimens were collected from Bjerkandera adusta (Willd.) P. Karsten and Porodaedalea sp. (both are fleshy polypore fungi) on a beech log, or on dead, standing beech trees in a mature to old-growth and predominantly hardwood forest. One individual was captured in a Lindgren funnel trap in a mature to old red oak forest. Several specimens of this species were found in company with T. schwarzi in a decaying fleshy polypore fungus on a standing, dead Populus sp. in a hardwood forest in Saint-Raphaël (15.VII.2006), Quebec (Webster, unpublished). Adults from New Brunswick were collected during June, August, and September. The habitat data above suggest that this species might be specialized on fleshy 
polypore fungi and related species that grow on dead standing trees or logs. Campbell (1982) noted that this species appeared to be becoming increasingly rare and suggested that it might be associated with old-growth hardwood forests, which are disappearing from most of eastern North America. However, more sampling should be done in forests of various ages to establish if this species is indeed an old-growth associate.

Distribution in Canada and Alaska. ON, QC, NB (Campbell 1982).

\section{Mycetoporus americanus Erichson, 1839**}

http://species-id.net/wiki/Mycetoporus_americanus

Map 24

Material examined. New Brunswick, Restigouche Co., Berry Brook P.N.A., $47.8140^{\circ} \mathrm{N}, 66.7578^{\circ} \mathrm{W}, 26 . \mathrm{V} .2007$, R. P. Webster, old growth eastern white cedar swamp, in moss on hummock at base of tree (1, RWC).

Collection and habitat data. Campbell reported that most adults of this species were collected along stream and lake margins. In Alberta, this species was associated with mature forests (Pohl et al. (2007). The New Brunswick specimen was collected from moss on a hummock at the base of a tree in an old-growth eastern white cedar swamp during May.

Distribution in Canada and Alaska. AK, YT, AB, BC, SK, ON, QC, NB, LB, NF (Campbell 1991).

\section{Mycetoporus rugosus Hatch, 1957}

http://species-id.net/wiki/Mycetoporus_rugosus

Map 25

Material examined. New Brunswick, Queens Co., Grand Lake near Scotchtown, $45.8762^{\circ} \mathrm{N}, 66.1816^{\circ} \mathrm{W}, 30 . \mathrm{IV} 2006$, R. P. Webster, oak and maple forest in leaves at base of oak (1, RWC); same locality and collector, 25.V.2006, lakeshore, in drift material (1, RWC). Charlotte Co., Rt. 3 at Deadwater Brook, $45.4745^{\circ} \mathrm{N}, 67.1225^{\circ} \mathrm{W}$, 23.IV.2006, R. P. Webster, black spruce forest, in sphagnum (1, RWC); $3.0 \mathrm{~km} \mathrm{NW}$ of Pomeroy Ridge, $45.3059^{\circ} \mathrm{N}, 67.4343^{\circ} \mathrm{W}, 16 . V I .2008$, R. P. Webster, old growth eastern white cedar swamp, in leaves and moss near small vernal pool (1, RWC). Northumberland Co., $12 \mathrm{~km} \mathrm{SSE}$ of Upper Napan, $46.8991^{\circ} \mathrm{N}, 65.3682^{\circ} \mathrm{W}, 7 . V I .2006$, R. P. Webster, old growth eastern white cedar swamp, in moss and leaf litter (1, RWC). Restigouche Co., Little Tobique River near Red Brook, $47.4462^{\circ} \mathrm{N}, 67.0689^{\circ} \mathrm{W}, 24 . \mathrm{V}^{2} 2007$, R. P. Webster, old growth eastern white cedar swamp, in moss and leaf litter near brook (1, RWC); NE of confluence of Little Tobique River and Red Brook, $47.4501^{\circ} \mathrm{N}$, $67.0577^{\circ} \mathrm{W}, 24 . \mathrm{V} .2007$, R. P. Webster, old growth eastern white cedar swamp, in sphagnum (1, RWC); MacFarlane Brook P.N.A., 47.6018 N, 67.6263W, 25.V.2007, R. P. Webster, old growth eastern white cedar swamp, in moss near brook (1, RWC). 


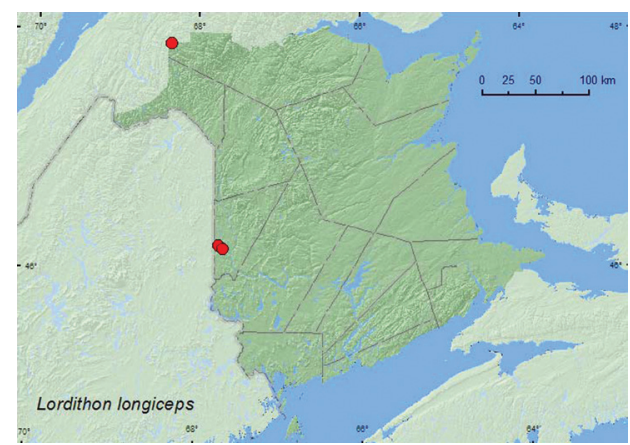

Map 19. Collection localities in New Brunswick, Canada of Lordithon longiceps.

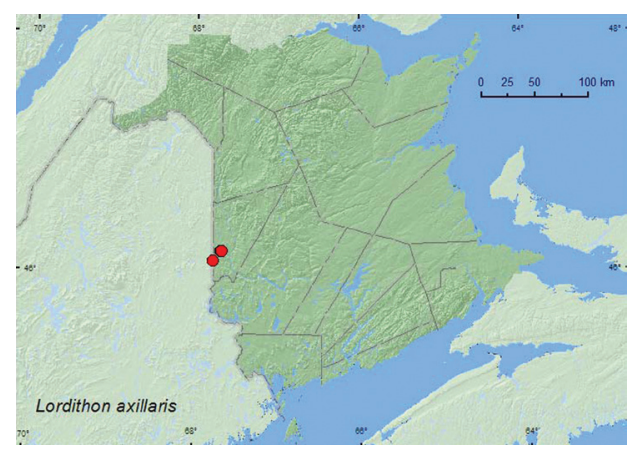

Map 2I. Collection localities in New Brunswick, Canada of Lordithon axillaris.

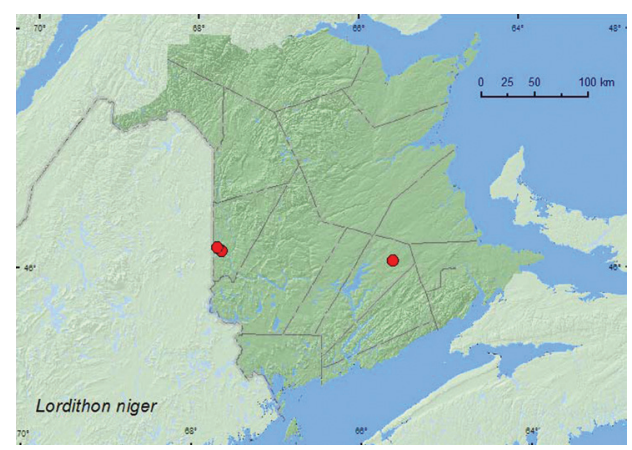

Map 23. Collection localities in New Brunswick, Canada of Lordithon niger.

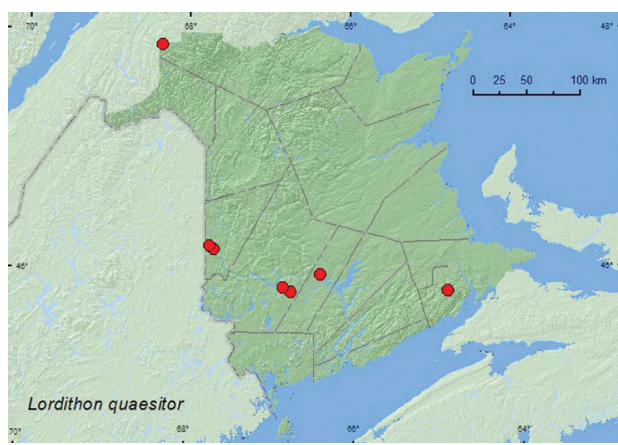

Map 20. Collection localities in New Brunswick, Canada of Lordithon quaesitor.

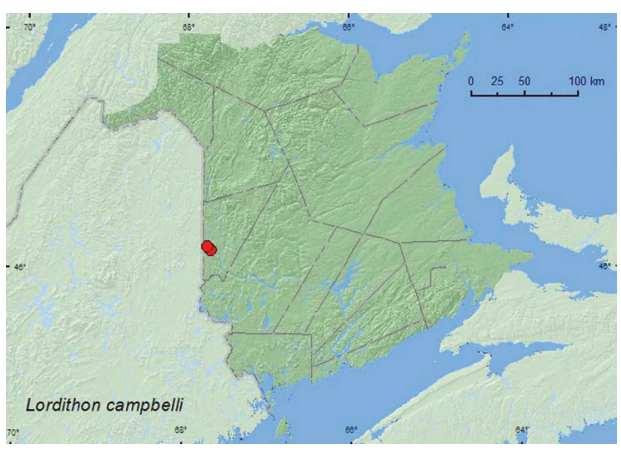

Map 22. Collection localities in New Brunswick, Canada of Lordithon campbelli.

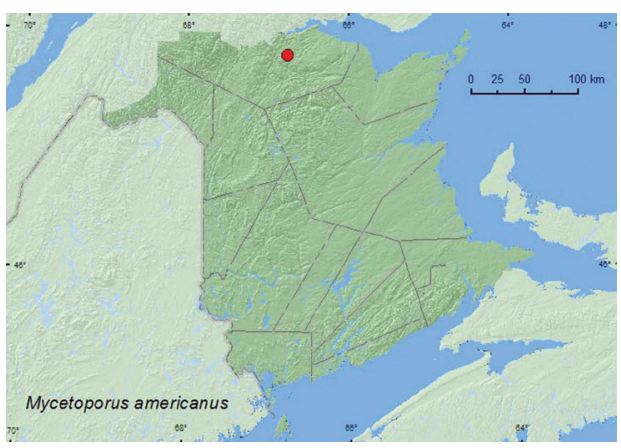

Map 24. Collection localities in New Brunswick, Canada of Mycetoporus americanus.

Saint John Co., ca. $2 \mathrm{~km} \mathrm{NE}$ of Maces Bay, $45.1161^{\circ} \mathrm{N}, 66.4560^{\circ} \mathrm{W}, 8 . \mathrm{V} .2006$, R. P. Webster, eastern white cedar swamp, in sphagnum near brook (1, RWC).

Collection and habitat data. Adults of $M$. rugosus have been collected from a wide variety of moist (often deep and moldy) litter and moss, including both decidu- 


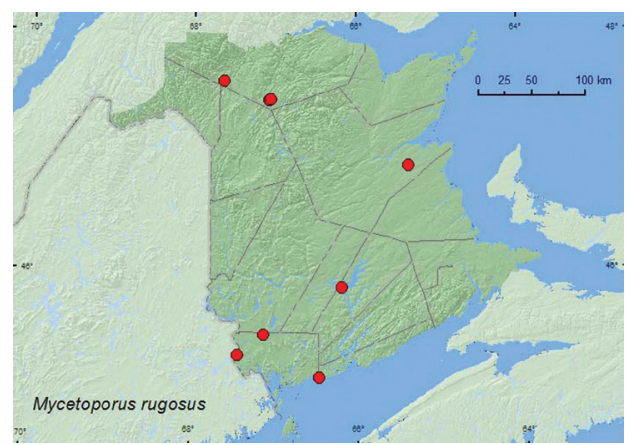

Map 25. Collection localities in New Brunswick, Canada of Mycetoporus rugosus.

ous and conifer litter of various species in forested habitats, as well as lake, stream, and river margins (Campbell 1991). New Brunswick specimens were collected from similar habitats, most frequently from moss and litter near brooks in old-growth eastern white cedar swamps. Adults were also collected from drift material and oak leaf litter along a lakeshore and from sphagnum in a black spruce forest. Adults from New Brunswick were collected during May and June.

Distribution in Canada and Alaska. AK, NT, YT, BC, AB, SK, MB, ON, QC, NB, NS, LB (Campbell 1991)

\section{Acknowledgments}

We thank Caroline Simpson for editing this manuscript and two anymous reviewers for the helpful suggestions. Jan Klimaszewski (NRCan, CFS - Laurentian Forestry Centre, Ste-Foy, Quebec), Greg Pohl, and David Langor (NRCan, CFS - Northern Forestry Centre, Edmonton, Alberta) revised the first draft of this manuscript and provided very useful comments. Anthony Davies (Agriculture and Agri-Food Canada (CNC), Ottawa) is thanked for supplying records, determining specimens, and other assistance with this project. We thank Stephen Clayden and David Malloch (New Brunswick Museum) for assistance with determining mushroom species. Nichole Brawn, Katie Burgess, Jim Edsall, Marie-Andrée Giguère, Aaron Fairweather, Graham Forbes, Nancy Harn, Cory Hughes, Rob Johns, Ervin Kovacs, Marsell Laity, Colin MacKay, Wayne MacKay, Jessica Price, Michelle Roy, Martin Turgeon, and Vincent Webster are thanked for technical assistance and collecting specimens. Martin Turgeon is thanked for assistance in locating collecting sites in northwestern New Brunswick. We thank Natural Resources Canada Canadian Forest Service; the Canadian Food Inspection Agency; and USDA APHIS for funding the Lindgren funnel trapping component of this study. The Canadian Wildlife Service is thanked for funding insect surveys at the Shepody National Wildlife Area, the New Brunswick Environmental Trust Fund and 
New Brunswick Wildlife Trust Fund for funding various insect surveys over the past 7 years, and the Meduxnekeag River Association for permission to sample beetles at the Meduxnekeag Valley Nature Preserve (which includes the Bell Forest). The New Brunswick Department of Natural Resources (Fish and Wildlife Branch) is thanked for issuing permits for sampling in the Protected Natural Areas and for logistical support. Survey work in the Jacquet River Gorge and Caledonia Gorge Protected Natural Areas was organized through the New Brunswick Museum with external funding from the New Brunswick Environmental Trust Fund, Salamander Foundation, and the New Brunswick Wildlife Trust Fund.

\section{References}

Bishop DJ, Majka CG, Bondrup-Nielsen S, Peck SB (2009) Deadwood and saproxylic beetle diversity in naturally disturbed and managed spruce forests in Nova Scotia. In: Majka CG, Klimaszewski J (Eds) Biodiversity, biosystematics, and ecology of Canadian Coleoptera II. ZooKeys 22: 309-340. doi: 10.3897/zookeys.22.144

Bouchard P, Bousquet Y, Davies AE, Alonso-Zarazaga MA, Lawrence JF, Lyal CHC, Newton AF, Reid CAM, Schmitt M, Ślipiński SA, Smith ABT (2011) Family-group names in Coleoptera (Insecta). ZooKeys 88: 1-972. doi: 10.3897/zookeys.88.807

Brunke AJ, Marshall SA (2011) Contributions to the faunistics and bionomics of Staphylinidae (Coleoptera) in northeastern North America: discoveries made through study of the University of Guelph Insect Collection, Ontario, Canada. ZooKeys 75: 29-68. doi: 10.3897/ zookeys.75.767

Buddle CM, Langor DW, Pohl GR, Spence JR (2006) Arthropod responses to harvesting and wildfire: implications for emulation of natural disturbance in forest management. Biological Conservation 128: 346-357. doi: 10.1016/j.biocon.2005.10.002

Campbell JM (1973) A revision of the genus Tachinus (Coleoptera: Staphylinidae) of North and Central America. Memoirs of the Entomological Society of Canada 90: 1-137. doi: $10.4039 /$ entm $10590 \mathrm{fv}$

Campbell JM (1975a) A revision of the genera Coproporus and Cilea (Coleoptera: Staphylinidae) of American North of Mexico. The Canadian Entomologist 107: 175-216. doi: 10.4039/Ent107175-2

Campbell JM (1975b) New species and records of Tachinus (Coleoptera: Staphylinidae) from North America. The Canadian Entomologist 107: 87-94. doi: 10.4039/Ent10787-1

Campbell JM (1976) A revision of the genus Sepedophilus Gistel (Coleoptera: Staphylinidae) of America north of Mexico. Memoirs of the Entomological Society of Canada 99: 1-89. doi: $10.4039 /$ entm $10899 \mathrm{fv}$

Campbell JM (1979) A revision of the genus Tachyporus Gravenhorst (Coleoptera: Staphylinidae) of North and Central America. Memoirs of the Entomological Society of Canada 109: 1-95. doi: 10.4039/entm111109fv

Campbell JM (1980) A revision of the genus Carphacis des Gozis (Coleoptera: Staphylinidae) of North America. The Canadian Entomologist 112: 935-953. doi: 10.4039/Ent112935-9 
Campbell JM (1982) A revision of the genus Lordithon Thomson of North and Central America (Coleoptera: Staphylinidae). Memoirs of the Entomological Society of Canada 119: 1-116. doi: 10.4039/entm114119fv

Campbell JM (1988) New species and records of North American Tachinus Gravenhorst (Coleoptera: Staphylinidae). The Canadian Entomologist 120: 231-295. doi: 10.4039/ Ent120231-3

Campbell JM (1991) A revision of the genera Mycetoporus Mannerheim and Ischnosoma Stephens (Coleoptera: Staphylinidae: Tachyporinae) of North and Central America. Memoirs of the Entomological Society of Canada 119: 1-169. doi: 10.4039/entm123156fv

Campbell JM (1993a) A review of the species of Nitidotachinus new genus (Coleoptera: Staphylinidae: Tachyporinae). The Canadian Entomologist 125: 521-548. doi: 10.4039/ Ent125521-3

Campbell JM (1993b) A revision of the genera Bryoporus Kraatz and Bryophacis Reitter and two related genera from America North of Mexico (Coleoptera: Staphylinidae: Tachyporinae). Memoirs of the Entomological Society of Canada 166: 1-85. doi: 10.4039/entm125166fv Campbell JM, Davies A (1991) Family Staphylinidae rove beetles. In: Bousquet Y (Ed) Checklist of Beetles of Canada and Alaska. Research Branch Agriculture Canada Publication 1861/E, 86-124.

Klimaszewski J, Sweeney J, Price J, Pelletier G (2005) Rove beetles (Coleoptera: Staphylinidae) in red spruce stands, eastern Canada: diversity, abundance, and descriptions of new species. The Canadian Entomologist 137: 1-48. doi: 10.4039/n03-123

Klimaszewski J, Langor D, Majka CG, Bouchard P, Bousquet Y, LeSage L, Smetana A, Sylvestre, P, Pelletier G, Davies A, DesRochers P, Goulet H, Webster R, Sweeney J (2010) Review of Adventive Species of Coleoptera (Insecta) Recorded from Eastern Canada. Pensoft Publishers, Sofia, Bulgaria, 272 pp.

Majka CG, Chandler DS, Donahue CP (2011) Checklist of the beetles of Maine, USA. Empty Mirrors Press, Halifax, Nova Scotia, 328 pp. doi: 10.4039/n06-099

Majka, CG, Klimaszewski J (2008) Introduced Staphylinidae (Coleoptera) in the Maritime provinces of Canada. The Canadian Entomologist 140: 48-72.

Newton AF, Thayer MK, Ashe JS, Chandler DS (2000) [2001] Family 22. Staphylinidae Latreille, 1802. In: Arnett RH, Thomas MC (Eds) American Beetles. Volume 1. Archostemata, Myxophaga, Adephaga, Polyphaga. CRC Press, Boca Raton, Florida, xv + 272-418.

Paquin P, Dupérré N (2001) Beetles of the boreal: a faunistic survey carried out in western Quebec. Proceedings of the Entomological Society of Ontario 132: 57-98.

Pohl GR, Langor DW, Spence JR (2007) Rove beetles and ground beetles (Coleoptera: Staphylinidae, Carabidae) as indicators of harvest and regeneration practices in western Canadian foothills forests. Biological Conservation 137: 294-307. doi: 10.1016/j.biocon.2007.02.011

Webster RP, Klimaszewski J, Pelletier G, Savard K (2009) New Staphylinidae (Coleoptera) records with new collection data from New Brunswick, Canada. I. Aleocharinae. In: Majka CG, Klimaszewski J (Eds) Biodiversity, biosystematics, and ecology of Canadian Coleoptera II. ZooKeys 22: 171-248. doi: 10.3897/zookeys.22.152 
Webster RP, Smetana A, Sweeney JD, DeMerchant I (2012) New Staphylinidae (Coleoptera) records with new collection data from New Brunswick and an addition to the fauna of Quebec: Staphylininae. In: Klimaszewski J, Anderson R (Eds) Biosystematics and Ecology of Canadian Staphylinidae (Coleoptera) II. ZooKeys 186: 293-348. doi: 10.3897/ zookeys.186.2469 